\title{
Using Web-assisted Instruction to Improve Student Achievement in English as a Foreign Language
}

\author{
Chia-Hsiu Tsao \\ Language Education Center, Fooyin University, Taiwan (R.O.C.) \\ E-mail: en016@fy.edu.tw
}

Received: November 9, 2014 Accepted: November 19, 2014 Published: January 10, 2015

doi:10.5296/ijele.v3i1.6656 URL: http://dx.doi.org/10.5296/ijele.v3i1.6656

\begin{abstract}
This study investigated the effects of web-assisted instruction (WAI), as compared with sole use of traditional face-to-face classroom instruction, on student learning of English as a foreign language by adopting a pretest-posttest control-group quasi-experimental design. The participants included 183 students from four intact classes in a technological university in southern Taiwan. A standardized English proficiency test was utilized as the pretest and posttest to measure student progress over an 18-week period. The results showed that (1) WAI is more effective than traditional instruction alone in improving students' posttest performance, (2) active participants in the online course achieve higher scores than passive ones in the posttest, (3) WAI has no differential effects for students of different ability levels, and (4) the experimental students acknowledged the advantages of WAI, but held reserved attitudes towards WAI. This study suggests that web-based learning be incorporated into the curriculum to provide students with additional learning in English, that students be guided and monitored throughout the process to ensure online learning success, and that teaching strategies be developed to encourage students to take control and responsibility for their own learning.
\end{abstract}

Keywords: web-assisted instruction; traditional instruction; online learning, student achievement 


\section{Introduction}

\subsection{Background}

Traditional instruction (TI), characterized by teacher-centered, lecture-based and direct face-to-face teaching in which students are instructed by the teacher to study the textbook and take notes (Sungur \& Tekkaya, 2006), is often criticized for its rigidness in teaching procedures, its failure to meet individual differences and arouse student interests, and most importantly, its ineffectiveness in raising student achievement (The China Post Editorial, 2007; Tsao, 2011). To compensate for the problems encounterd by TI, many teachers have experimented with the use of the web technologies and resources to supplement in-class instruction. On the one hand, web-based learning resources equip teachers with a variety of authentic materials to enrich and vitalize their teaching. On the other, it enables students to obtain additional learning at their convenience and at their own pace.

Although many pedagogical benefits are associated with web-assisted instruction (WAI), including the use of multi-media, authenticity and variety of materials, flexibility and customization of learning, and opportunities for guided learning (Hiltz \& Wellman, 1997; Liaw, 2001), the implementation of it does not guarantee success. The focus of WAI does not lie in whether the instructional materials have been uploaded to the e-platform, but rather in whether the students have logged online to learn the materials (Wu, 2004). The learner's lack of self-sustaining or self-learning capability, losing learning directions, or experiencing frustration are all negative factors. A good online learning platform should allow the teacher to interact with the learners in some way and simultaneously monitor their learning progress (Roberts \& McInnerney, 2007). It must be flexible and allow for differences in learning styles and abilities. In the online learning environment novice web users may easily lose direction and experience frustration in learning. Aimless surfing of the Internet makes them unable to establish a comprehensive framework of knowledge, or causes cognitive overload on them, making it difficult to integrate knowledge structure (Martin, 1994; Warschauer, 2000). Therefore, WAI requires clear teaching objectives and sound curriculum planning to guide the learners while at the same time overseeing student learning behavior and progress, and trying to maintain their motivation to learn (Chang, 2005; Lai, 2008; Lee, Shen \& Tsai, 2010).

While more and more teachers utilize the Internet resources to support instruction, there is also a growing concern regarding how effective the web is as an instructional tool. Previous studies that evaluated the impact of WAI on student achievement have mostly reported positive findings, as concluded in the meta-analyses of Zhao, Lei, Yan, Lai, and Tan (2005); Sitzmann, Kraiger, Stewart and Wisher (2006); and Liao (2007). Nevertheless, little empirical research exists that examines the effects of WAI on language learning; most of the previous studies applied WAI to content courses such as math, science, computing, and writing, with few addressing English as a foreign or second language (EFL/ESL) learning. The scanty research that is available in the EFL or ESL context has come to conflicting results. On the positive side, we find studies that confirmed the superiority of WAI over TI in 
English writing performance (Al-Jarf, 2004b; Chuo, 2007; Kargozari \& Hamed, 2010; Liou, 1997), English reading comprehension (Dreyer \& Nel, 2003; Pan \& Huang, 2009; Tanyeli, 2008) and English speaking (Chiu, Liou \& Yeh, 2007). On the downside, there are studies that detected no significant differences in learning performance between online students and traditional classroom students (Lin, 2007; Liu, 2007; Shiu, 2002).

\subsection{Statement of the Problem}

Since the effectiveness of WAI in facilitating language learning remains inconclusive, more experimental studies appear necessary. Moreover, hardly any previous studies have included participants from technological colleges or universities, whose students have a pressing need for English language proficiency in the workplace but are seriously undertrained in English to compete successfully (Chen, 2002; Tsao \& Hsu, 2010). Technical college students in Taiwan are commonly unmotivated in the classroom and severely deficient in English language skills. According to a study by Tsao \& Hsu (2010), the majority spent one hour or less per week on English study after class. Therefore, it comes as no surprise that many of the technical college students graduate without the ability to write or speak simple English which they have learned since elementary schools ( $\mathrm{Su}, 2005$; Liao, 2010). In fact, according to a report released by Taiwan's Ministry of Education (MOE), less than 10\% of the freshman students from private colleges and universities passed the basic level of General English Proficiency Test (GEPT), a locally-developed standardized language test (the Liberty Times, 2009). Thus, how to enhance students' English proficiency has become one of the most important tasks for higher education in Taiwan in recent years, consequently prompting almost all colleges and universities to set up an English graduation threshold and request their undergraduates to pass at least the basic level of any English standardized test such as TOEIC or TOEFL (Hsu \& Wang, 2006; Chen \& Huang, 2007).

\subsection{Purpose}

In view of the students' need to meet the English graduation requirement, the researcher developed an online learning scheme to prepare students for standardized exams. However, as vocational-technical students tend to be passive learners and low achievers of English (Lee, Shen \& Tsai, 2008), the researcher wondered if they were able to benefit from web-assisted language learning, which requires much time commitment and active engagement on the part of the learner. In addition, the researcher would also like to know if learner participation and English proficiency are two important variables that influence the learning outcomes of these students: whether active participants who get more involved and spend more hours doing online learning will outperform those who do otherwise in the posttest, and whether more proficient students of English will benefit more from the online course than the less proficient ones.

\subsection{Research Questions}

To sum up, the current research, using technological students as the subjects, aims to explore how WAI as a supplement to TI enhances their learning of English as a foreign language by addressing the following questions: 
(1) Does WAI result in better student outcomes than TI?

(2) Does degree of participation in online learning have any impact on learning outcomes?

(3) Does WAI have differential effects for students of different proficiency levels?

(4) How do experimental group students perceive and evaluate WAI as compared with TI?

\subsection{Definitions of Terms}

- Traditional instruction (TI): TI in this study refers to the use of the blackboard and textbooks (or handouts) by the teacher to conduct face-to-face lessons to the students in the classroom.

- Web-assisted Instruction (WAI): WAI in this study refers to the use of web-based learning resources and activities by the teacher to supplement classroom teaching so as to provide students with additional learning opportunities out of class. It is different from blended learning, which integrates face-based instruction and computer-based instruction, in that WAI enhances classroom teaching with web resources and activities instead of online or computer-mediated instruction.

- Technological students: Technological students in this study refer to students who are enrolled in technological colleges or universities, and graduate with a B.A. or B.S. degree.

\section{Methodology}

\subsection{Participants}

The participants were 4 intact classes of students, totalling 183, in a technological university in southern Taiwan, with an average age of 18.6 and an average length of 9.7 years' English study. At the time of this study, they were taking a two-hour-weekly required general English (GE) course from the teacher-researcher. The course focused on the training of reading and listening skills at the high-beginning level. Two classes were randomly assigned to the experimental group $(n=94)$, receiving supplementary WAI, and the other two to the control group $(n=89)$, receiving traditional classroom instruction only. All participants in this study, together with other students in the same university, are required to pass the basic level of GE proficiency tests before graduation.

\subsection{Intervention}

Previous studies have pointed out that a voluntary online self-learning program is likely to fail with students who are passive and unmotivated (Lai, 2008). Therefore, to ensure a successful execution of web-assisted language learning, the instructor made it a compulsory part of the course by building the student's performance in online learning into his or her final grade of the course.

The teaching intervention lasted for 18 weeks. Both experimental and control students were taught by the teacher-researcher, receiving the same in-class instruction, using the same textbook, following the same syllabus, and taking the same midterm and final exams that 
together account for $50 \%$ of the semester grade, a practice adhering to the school policy which stipulates that the textbook and course assessment should remain consistent among classes of the same year.

However, with another half of the course grade at the teacher's disposal, the teacherresearcher was able to vary part of the teaching practice for the two groups. For the control group, $20 \%$ of the course grade was allotted to self-study of two teacher-selected simplified classic readers with audio CDs, and the assessment included a reading reflection report and a pen-and-paper test, whereas for the experimental group, students were required to fulfil a self-learning task that involved the completion of online assignments and the taking of the tests related to the assignments. They were also encouraged to take notes of what they had learned from each website they visited and submitted their notes to the instructor to earn extra credits.

For that purpose, a dedicated page which provides links to a selection of websites accessible free on the Internet was created by the teacher-researcher and posted on the course website, along with a brief instruction on what to do with each of the connected sites (see Appendix 1). These websites, as listed below, were selected because they are in line with the students' English levels and contain tutorials, drills, exercises, worksheets or tests that prepare students for the standardized English proficiency tests in real life.

- Listening: Rendall's ESL Cyber Listening Lab (http://www.esl-lab.com/)

- Reading Station (http://etlc.wtuc.edu.tw/reading/reading_articles.php)

- Vocabulary: EPT Basic 1200 Words (http://www.ept-xp.com/?ID=22100919)

- Grammar: Basic English Grammar (http://210.240.55.2/ t311/moe/engb5/diagnose/diagtable.htm)

- Test-Taking Practice: General English Proficiency Test (http://140.127.98.66/amc_elrn/login.aspx)

Instructions on how to use certain websites were given by the teachers in the computer lab and also posted in the "Announcements" area of the e-learn platform. Students could access these websites from anywhere and at any time, pacing their learning progress at their own convenience. After students completed an exercise on a particular website, they would receive immediate feedback and a score through the interactive mechanism of that website. They would know where they made mistakes and how they could correct them. Students were guided about the self-learning project and the use of these websites in the first week. A study plan with a testing schedule was also given to the experimental students at the onset of the course. It was expected that the experimental students' learning of the foreign language could be effectively enhanced and improved through additional exposure to the English language and a variety of online assignments and tasks given by the teacher.

\subsection{Instruments}

\subsubsection{An English Language Proficiency Test}

An elementary-level General English Proficiency Test (GEPT) - a criterion-referenced test 
developed by the Language Training and Testing Center in Taiwan and commonly adopted by many local schools as the English exit examination - was used as the pretest and posttest to measure student progress over time. The test consists of 30 listening and 35 reading comprehension questions in multiple-choice format, with a perfect scale score of 120 for each section. The experimental subjects' scores on the pretest were also used to differentiate the more proficient students from the less proficient ones in order to assess the effects of WAI on students of varied proficiency levels.

Many studies have been carried out to evaluate the validity and reliability of GEPT, which has been claimed to have high reliability and validity (Gong, 2002; LTTC, 2001; Wu, 2011).

\subsubsection{A Post-treatment Questionnaire}

A questionnaire concerning the experimental students' perceptions of the online-learning experience was developed by the teacher-researcher based on the objectives of this study and the work of Pan and Huang (2009) and Son $(2007$; 2008) and was validated by two senior experts in the field to establish its content validity. The questionnaire, in an anonymous form, was composed of (1) two questions that inquire about the time the subjects spent on online learning per week and the number of copies of study notes they produced per week, and (2) 16 questions that probe into the subjects' attitudes toward WAI in general, with responses rated on a 5-point Likert scale, ranging from "strongly agree" to "strongly disagree". The Cronbach's alpha coefficient of this scale for the current study is 0.89 , indicating that the scale measures responses with satisfactory internal consistency.

\subsubsection{A Post-treatment Interview}

To probe further into the experimental group's perceptions towards WAI, an interview was held one week after the questionnaire survey. The researcher randomly selected 3 students respectively from high-, mid-, and low-ability groups and interview them with an interview guide (see Appendix 2) to facilitate the interview process. The interview, which took about two hours, was audio-recorded and transcribed for thematic analyses.

\subsection{Procedures}

In the first week of the intervention both groups were pretested with an elementary- level GEPT. After the test a course orientation was given to familiarize the students with the course, but an extra tutorial on the online course components was included in the orientation to the experimental students. In the 16 weeks that followed, students in both groups did basically the same things inside the class, except that the experimental group studied web materials outside of class while the control group studied paper materials. In week 17, both groups took the GEPT posttest to see the treatment effects over time. In addition, the experimental group answered the post-treatment questionnaire. At the end of the intervention in week 18, an interview was given to nine selected students from the experimental group.

\subsection{Data Analysis}

The quantitative data were collected through a pretest, a posttest, and a questionnaire. The data were analyzed using SPSS for Windows 10.0, involving Cronbach's alpha reliability test, descriptive statistics and One-way ANCOVA. Using the pretest scores on GEPT as covariate 
and posttest scores as the dependent variable, One-way ANCOVA was conducted to determine whether significant differences existed in adjusted means of the dependent variables. Significance of difference between the mean scores of both groups was tested at the .05 level.

In addition, to ascertain the role of participation in the success of online learning, students in the experimental group were further divided into three subgroups (active, average and passive) according to students' self-reports in the questionnaire about the time they spent learning online and the quantity of study notes they produced while learning online. Those who spend more than 3 hours per week and take more than two A4 pages of notes in a week are classified into the active group; those who allot less than two hours and write fewer than one page of notes are grouped into the passive; and those in between are put into the average group. Finally, to detect the potential effects induced by language proficiency, the pretest scores were used to assign experimental students into high and low ability groups. Again, one-way ANCOVA was performed to determine the significant differences between groups.

As for the data collected through an interview, it was transcribed, analysed and crossreferenced with the quantitative data from the questionnaire.

\section{Results}

\subsection{WAI versus TI in terms of student outcomes in EFL learning}

Descriptive statistics in Table 1 report the posttest means before and after adjusting for the pretest scores. A significant difference was observed between the posttest scores of the two groups $(\mathrm{F}=7.71$ and 5.61 respectively, $\mathrm{p}<.05)$, in favor of the experimental group. The experimental group achieved significantly higher adjusted scores than the control group in both the listening and reading sections of the posttest (90.77 vs. 85.53 in listening, and 73.45 vs. 71.04 in reading), which implied the superiority of the web-assisted teaching approach over the traditional pure in-class instruction in promoting students' English competence in both listening and reading.

Table 1. Comparison of the Two Groups on the Posttest (One-Way ANCOVA)

\begin{tabular}{|c|c|c|c|c|c|c|c|c|c|}
\hline \multirow[t]{2}{*}{ Test } & \multirow[t]{2}{*}{ Group } & \multicolumn{2}{|c|}{ Pretest } & \multicolumn{2}{|c|}{$\begin{array}{c}\text { Posttest } \\
\text { Unadjusted }\end{array}$} & \multicolumn{2}{|c|}{$\begin{array}{l}\text { Posttest } \\
\text { Adjusted }\end{array}$} & \multirow[t]{2}{*}{$\mathrm{F}$} & \multirow[t]{2}{*}{$p$} \\
\hline & & M & S.D. & $\mathrm{M}$ & S.D. & $\mathrm{M}$ & S.E. & & \\
\hline \multirow{2}{*}{ Listen } & $\exp ^{\mathrm{a}}$ & $81.32^{c}$ & 16.43 & 91.06 & 17.62 & 90.77 & .88 & \multirow{2}{*}{$7.71^{* *}$} & \multirow{2}{*}{.006} \\
\hline & con. $^{\mathrm{b}}$ & 79.10 & 12.84 & 85.53 & 16.21 & 85.53 & .91 & & \\
\hline \multirow{2}{*}{ Read } & exp. & 67.55 & 18.34 & 74.77 & 15.78 & 73.45 & .71 & \multirow{2}{*}{$5.61^{*}$} & \multirow{2}{*}{.019} \\
\hline & con. & 64.53 & 14.43 & 69.65 & 14.76 & 71.04 & .75 & & \\
\hline
\end{tabular}


${ }^{*} \mathrm{p}<.05 ;{ }^{* *} \mathrm{p}<.01$

\subsection{Impact of Participation Level on the Posttest Performance of WAI Students}

For the purpose of this session, the experimental group was broken down into three groups according to students' self-reports in the questionnaire about the time they spent learning online and the quantity of study notes (see Appendix 3 for student sample page) they produced while learning online: 17 students who reported dedicating more than 3 hours per week to the online project and taking more than two A4 pages of notes in a week were classified into the active group, 43 who reported spending between two to three hours and completing one to two pages of notes were put into the average group, and 34 who allotted less than two hours and wrote fewer than one page of notes were grouped into the passive. Then, one-way ANCOVA was performed to investigate if there was a significant difference in the posttest among the three groups. The results displayed in Table 2 indicated a significant difference among the adjusted means of the three groups $\left[\mathrm{F}_{(2,90)}=6.41, \mathrm{p}<0.01\right]$. Bonferroni post hoc tests as shown in Table 3 further confirmed that the active group $(M=175.53$, $\mathrm{SE}=1.96)$ made significantly greater gains than the average $(\mathrm{M}=166.74, \mathrm{SE}=3.22)$ and the passive group $(\mathrm{M}=158.99, \mathrm{SE}=2.59)$, which implies the importance of learner participation or involvement in online learning.

Table 2. Comparison of Posttest Performances by Participation Level in Online Learning (One-Way ANCOVA)

\begin{tabular}{|c|c|c|c|c|c|c|c|c|}
\hline \multirow{2}{*}{ Group } & \multicolumn{2}{|c|}{ Pretest } & \multicolumn{2}{|c|}{ Unadjusted } & \multicolumn{2}{|c|}{ Adjusted } & \multirow{2}{*}{$F$} & \multirow{2}{*}{$P$} \\
\hline & $\mathrm{M}^{\mathrm{a}}$ & S.D. & M & S.D. & M & S.E. & & \\
\hline $\begin{array}{l}\text { Active } \\
(\mathrm{N}=17)\end{array}$ & 170.96 & 21.39 & 194.82 & 28.53 & 175.53 & 2.99 & & \\
\hline $\begin{array}{l}\text { Average } \\
(\mathrm{N}=43)\end{array}$ & 159.96 & 16.36 & 176.45 & 16.89 & 166.74 & 1.82 & $6.41^{* *}$ & .002 \\
\hline $\begin{array}{l}\text { Passive } \\
(\mathrm{N}=34)\end{array}$ & 123.79 & 21.39 & 137.09 & 21.37 & 158.99 & 2.40 & & \\
\hline
\end{tabular}

a The means are the added scores of the listening and reading sections of the posttest, and the total maximum is 240 .

** $\mathrm{p}<.01$

Table 3. Post Hoc Tests of the Relationship between Participation and GEPT Posttest Adjusting for the Pretest

\begin{tabular}{cccc}
\hline $\mathrm{A}^{\mathrm{a}}$ & $\mathrm{B}$ & $\begin{array}{c}\mathrm{A}-\mathrm{B}^{\mathrm{b}} \\
\text { (mean difference) }\end{array}$ & Sig. \\
\hline 1.00 & 2.00 & $8.78^{*}$ & .043 \\
& 3.00 & $16.54^{* *}$ & .002 \\
2.00 & 3.00 & 7.76 & .096 \\
\hline
\end{tabular}


${ }^{\mathrm{a}} 1=$ active participation group; $2=$ average participation group; $3=$ passive participation group

${ }^{\mathrm{b}}$ Adjustment for multiple comparisons: Bonferroni.

${ }^{*} \mathrm{p}<.05 \quad{ }^{* *} \mathrm{p}<.01$

\subsection{Differential Effects of WAI on the Posttest Performance of High and Low Achievers}

Students in the experimental group with pretest scores in the top and bottom $33 \%$ of the distribution formed a high and a low English ability group, resulting in a total of 32 students in the high group and 30 in the low group. The results of one-way ANCOVA as displayed in Table 4 demonstrate no significant differences between the adjusted means of the two groups on either the listening or reading posttests $(\mathrm{F}=0.36$ and 2.42 respectively, $\mathrm{p}>.05)$, suggesting that the WAI produced no differential effects for students of either high or low levels. In other words, WAI is as effective for high achievers as for low achievers in improving their English listening and reading abilities.

Table 4. Comparison of Posttest Performances by High- and Low-level Experimental Students (One-Way ANCOVA)

\begin{tabular}{lccccccccc}
\hline \multirow{2}{*}{ Test } & \multirow{2}{*}{ Group } & \multicolumn{2}{c}{ Pretest } & \multicolumn{2}{c}{ Unadjusted } & \multicolumn{2}{c}{ Adjusted } & \multirow{2}{*}{ F } & $p$ \\
& & M & S.D & M & S.D & M & S.E. & & \\
\hline \multirow{2}{*}{ Listen } & high $^{\mathrm{a}}$ & 98.35 & 7.11 & 107.53 & 11.34 & 89.29 & 2.62 & & \\
& low $^{\mathrm{b}}$ & 63.33 & 9.97 & 72.54 & 12.16 & 93.21 & 2.78 & 0.85 & .361 \\
& high & 79.97 & 8.04 & 86.62 & 9.93 & 77.13 & 1.91 & & \\
Read & low & 53.71 & 6.45 & 60.68 & 10.99 & 71.44 & 2.11 & & \\
& & &
\end{tabular}

${ }^{a}$ high $=$ students with overall pretest scores in the top $33 \%(\mathrm{~N}=32)$

${ }^{\mathrm{b}}$ low $=$ students with overall pretest scores in the bottom $33 \%(\mathrm{~N}=30)$

\subsection{Perception and Evaluation of WAI as Compared with TI by Experimental Group Students}

As Table 5 reveals, experimental students are rather divided in their responses to the survey questions, suggesting the WAI as a new approach to teaching has generated controversy among them. The data showed that the new approach neither encouraged nor discouraged most of the students. However, it did affect a small group of students (approximately one-fourth) positively and a nearly equivalent number of students negatively. For example, more students agreed than disagreed that WAI is interesting (item 1) and effective (item 2). Yet by contrast, more students felt that WAI decreases learning motivation (item 3) and creates more pressure (item 4). While over half of the students (item 5) consider WAI time-consuming, a greater majority (item 6) acknowledged its abundance and diversity. Despite the many benefits of WAI such as leaving a deeper impression on what is learned and contributing more to English-learning, as approved by the majority of students in item 7 and 8, students did not favour it over TI as revealed in item 9, where half of the students held a neutral position while more students disliked WAI (29\%) than those who supported it (21\%). 
The reason may be contributed to fact that web-assisted learning in this study was made compulsory rather than voluntary, thus resulting in reluctance on the part of the learners. Results of item 10 to 12 seem to endorse the teacher's proper selection of the websites. The majority of students thought teacher-selected websites offer English-learning resources which meet their ability levels and learning needs, thus serving as useful supplementary materials. Regrettably, however, only one-fourth of the students wanted the teacher to recommend more English-learning websites to them, while the rest were either not sure or opposed to the idea (item 13). Finally, results of item 14 and 15 revealed students' passiveness toward online learning and mixed feelings toward tests. While $38 \%$ of the students thought tests were necessary, only $22 \%$ confessed that they would go online to learn English even without tests, and a much larger number of students (42\%) indicated they would not learn online if there were no tests.

Table 5. Evaluation of Web-Assisted Instruction by Experimental Students $(\mathrm{N}=94)$

Queries

SD\&D $\% \quad \mathrm{~N} \% \quad \mathrm{SA} \& \mathrm{~A} \%$

\section{Compared with traditional instruction, I think web-assisted instruction...}

1 . is more interesting.

$\begin{array}{lll}25.5 & 44.7 \quad 29.8\end{array}$

2. is more effective.

$21.3 \quad 46.8 \quad 31.9$

3. can better increase my learning motivation.

$34.0 \quad 42.6 \quad 23.4$

4. creates more pressure in learning English.

$24.5 \quad 40.4 \quad 35.1$

5. requires more study time in English.

$18.1 \quad 28.7 \quad 53.2$

6. provides more abundant and diverse learning content.

$20.2 \quad 16.0$

63.8

7. leaves a deeper impression on what is learned.

$23.4 \quad 33.0 \quad 43.6$

8. helps me more with English-learning.

$21.3 \quad 37.2 \quad 41.5$

\section{To sum up,....}

9. I prefer web-assisted instruction to traditional instruction. $\begin{array}{lll}28.7 & 50.0 & 21.3\end{array}$

$\begin{array}{llll}\text { 10. the online learning resources offered by teacher- } & 17.0 & 28.7 & 54.3\end{array}$ selected websites are useful supplementary materials.

$\begin{array}{llll}\text { 11. the online learning resources offered by teacher- } & 26.6 & 26.6 & 46.8\end{array}$ selected websites are suitable for my English level.

$\begin{array}{llll}\text { 12. the online English resources offered by teacher- } & 24.5 & 29.8 & 45.7\end{array}$ selected websites meets my learning needs.

13. I hope Teacher can recommend more English-learning $\quad 30.9 \quad 43.6 \quad 25.5$ websites to us.

14. I think it is necessary for Teacher to test us on what $\quad \begin{array}{lll}36.2 & 25.5 & 38.3\end{array}$ is learned online.

$\begin{array}{llll}\text { 15. I'd still go online to learn English even without tests. } & 41.5 & 36.2 & 22.3\end{array}$

$\mathrm{SD}=$ strongly disagree, $\mathrm{D}=$ disagree, $\mathrm{N}=$ neutral, $\mathrm{A}=$ agree, $\mathrm{SA}=$ strongly agree 
This study yielded survey findings different than did many previous studies (Al-Jarf, 2004a; Chang, 2005; Chiu, et al., 2007; Kung \& Chuo, 2002; Pan \& Huang, 2009; Son, 2007 \& 2008). For example, Pan and Huang (2009) reported over $80 \%$ of their participants enjoyed web-based learning more than reading paper materials. Al-Jarf (2004a) found all of his students who had used the online course held highly positive attitudes towards online learning with their motivation heightened and their self-esteem raised. The overwhelming majority of the subjects in Son's studies $(2007$; 2008) also enjoyed Web activities and indicated that they would access Web activities outside of class time and use the Web as a part of additional learning at home.

In order to ascertain why a good number of experimental students in this study responded unfavorably to web-learning, the teacher-researcher conducted an informal interview with a group of nine students one week after the questionnaire survey. According to the interviewees, the reasons why web-based learning didn't help raise learning interest or enhance motivation included:

- It takes too much time. English is only a minor subject for these nursing or medical students, who have major subjects to attend to. In addition, many of them have part-time jobs or extracurricular activities to take part in, so it is very difficult for them to spare time for online learning.

- It is a lot of hassle. They don't always have computers at hand or access to the Internet to do e-learning. They would rather read printed materials than dealing with technical problems such as frequent crashes and slow computer speed.

- It is kind of boring. Many websites are drill-based, which may be good for practice, but not attractive enough to engage interest. For many of them, doing online reading or exercises is pretty much like studying textbooks or taking classroom tests.

- It should not be counted toward the semester grade; instead, it should be used for granting bonus points.

- It places extra course load on them, while students in other classes are taught and tested what is in the textbook only.

- It causes physical discomfort such as eye strain or backache.

As online learning in this study was made a requirement as well as a test-preparatory measure rather than an option or a motivational stimulant, it came natural that it was not received as enthusiastically as in other studies where the participants were encouraged and often given extra points for taking part in it.

\section{Conclusion}

\subsection{Discussion of the Findings}

The major finding of this study supported earlier research that has proved the superiority of WAI over TI on language learning (Al-Jarf, 2005; Chang, 2005; Chiu et al., 2007; Fujishiro 
\& Miyaji, 2009; Liou,1997; Tanyeli, 2008). As a matter of fact, the meta-analysis study of Sitzmann, et.al (2006) has concluded that web-based instruction used as a supplement to classroom instruction is $19 \%$ more effective than conventional instruction when "Web-based trainees were provided with control, in long courses, and when trainees practiced the training material and received feedback during training (p. 623)" As the online course in this study was well planned and implemented, e-learning was made not only possible but also effective for less motivated underachievers such as the current subjects.

This study also supported the importance of participation in online learning. The finding that active participants made greater gains than passive ones in the posttest is in agreement with previous studies (Al-Jarf, 2004a; Liou,1997), suggesting that success in online learning depends considerably on learner autonomy and participation (Chang, 2005; Yukselturk \& Bulut, 2007). The more autonomous students are, the more time and efforts they will spend in learning by themselves, which in turn brings more academic success to them (Chang, 2007). Therefore, encouraging students to take initiative and depend on themselves more in learning is a crucial component that English language teachers should take into account when planning their curriculum (Benson, 2003; Lee, Shen \& Tsai, 2010).

However, this study did not find any differential effects of WAI for mixed-ability students, whereas in the study of Tabassum (2004) WAI was more effective for high achievers than for low achievers in improving achievement in science learning, and yet in the study of Liu, Chen and Chang (2010) a particular computer-assisted learning strategy termed concept mapping generated greater benefits for poor readers of English than for good readers. A possible reason for these discrepancies could relate to the study design. The online learning in this study was integrated into the course evaluation, forcing all students, both strong and weak, to work equally hard to meet the requirement, while in Tabassum's study web-learning was offered without causing extra course load; students were merely exposed to certain websites but not further tested on what they had learned online. In a voluntary learning environment better students tend to make more use of individualized e-learning than weaker students, and thus benefit more than the latter. As to the study of Liu et al. (2010), their concern was whether the learning strategy worked equally well for both good and poor readers in Freshmen English, and they explained their finding by claiming that poor readers made more progress because the strategy "promotes better understanding without too much loading for readers", while good readers showed no improvement because "they already have their own effective learning strategies and knowledge structure" (p. 442).

Finally, a survey of the experimental students showed mixed attitudes toward web-based learning. While most of them acknowledged the advantages of online learning, quite a few held negative perceptions of WAI and showed little interest in continuing with e-learning after completing the course. This finding has two implications: first, it suggests that test-oriented online learning is discouraging and uninteresting, hence failing to win widespread support from these students; second, technological students are probably more passive or less motivated learners of English than those in general universities. 


\subsection{Implications and Suggestions}

The results of this study have important implications for both EFL teaching and online instructional design. First of all, the finding that WAI was successful in improving technical students' GE proficiency suggests that web-assisted learning should be included as part of the English curriculum. As students in the conventional teaching context merely study units taught in the textbooks, the content they learn is insufficient. To supplement for the deficiency, the Internet can be employed as a useful tool to enhance teaching and learning.

Secondly, the finding that active participants made more progress than passive ones demonstrates the importance of learner involvement or autonomy in online learning. Therefore, teachers can help students develop strategies to self-monitor their own learning instead of taking full responsibility for their students. Future research may explore the role of learner autonomy and self-regulating strategies in web-enhanced EFL learning.

Thirdly, the finding that WAI had no differential effects for students of mixed abilities illustrates that low achievers can also benefit from web-based learning. However, for students limited in English proficiency, it is especially important that teachers select proper web sites and resources that are appropriate to them and provide guidance on how to use those resources, so as to minimize the potential difficulties that these students may encounter when learning via the Web.

Last but not the least, the experimental students' feedback from the questionnaire and the interview indicated that they were not all pleased to learn through the Internet. Many regarded online learning as an add-on to the regular class and thus considered it an extra burden. Therefore, this study suggests when incorporating online learning into the English curriculum, teachers need to develop strategies to encourage their students to take more control and responsibility for their own learning. Furthermore, the course objectives should be clearly defined, as they may determine how the online program is run. If increasing student learning interest is the main goal, the online learning part should probably not be made compulsory or test-oriented. Otherwise, too many tests or too much learning load would damage interest. However, if extending learning scope or raising achievement is the first priority, the proportion of the course grade allotted to the online learning component should probably be increased so that passive students would get more involved or pay more attention to it. After all, it is not always easy to achieve one without sacrificing the other. Future studies may include a third group of participants, who are offered the online supplement as an option rather than a requirement, and compare the three groups in terms of attitudes and achievement.

\section{References}

Al-Jarf, R. (2004a). Differential effects of online instruction on a variety of EFL courses. Paper presented at the annual meeting of the Asia Association of Computer Assisted Language Learning (AsiaCALL), Penang, Malaysia.

Al-Jarf, R. (2004b). The effects of web-based learning on struggling EFL college writers. Foreign Language Annals, 37(1), 49-57. 
Al-Jarf, R. (2005). The effects of online grammar instruction on low proficiency EFL college students' achievement. Asian EFL Journal, 7(4), 166-190.

Benson, P. (2003). Learner autonomy in the classroom. In D. Nunan (Ed.) Practical English language teaching (pp. 289 - 308). PRC: Higher education press/McGraw Hill.

Chang, M. M. (2005). Applying self-regulated learning strategies in a web-based instruction--an investigation of motivation perception. Computer Assisted Language Learning, 18(3), 217-230.

Chang, M. M. (2007). Enhancing web-based language learning through self-monitoring. Journal of Computer Assisted Learning, 23(3), 187-196.

Chen, L. M. (2002). Washback of a public exam on English teaching. Unpublished Ph.D. dissertation. Ohio: The Ohio State University.

Chen, T. H., \& Huang, S. J. (2007). The impacts of compulsory standardized exams on L2 learning motivation among college students. Paper presented at The 33rd Annual International Conference on Language Teaching and Learning, Tokyo, Japan.

Chiu, T. L., Liou, H. C., \& Yeh, Y. (2007). A study of web-based oral activities enhanced by automatic speech recognition for EFL college learning. Computer Assisted Language Learning, 20(3), 209-233.

Chuo, T.W. (2007). WebQuest writing instruction program on EFL learners' writing performance writing apprehension and perception. TESL-EJ, 11(3), 1-27.

Dreyer, C. \& Nel, C. (2003). Teaching reading strategies and reading comprehension within a technology-enhanced learning environment. System, 31, 349-365.

Fujishiro, N. \& Miyaji, I. (2009). Effectiveness of blended instruction in class on the skills of oral reading and speaking in English. Educational Technology Research, 32, 79-90.

Gong, B. (2002). Comparative studies of GEPT and PETS in Taiwan and China. Selected papers from the Eleventh International Symposium on English Teaching/Fourth Pan-Asian Conference.

Hiltz, S. R. \&Wellman, B. (1997). Asynchronous learning networks as a virtual classroom. Communications of the ACM, 40, 44-49.

Hsu, L. \& Wang, P. L. (2006). A study on English graduation threshold and English learning motivation. Journal of Kaohsiung University of Applied Sciences, 35, 51-67.

Kargozari, H. R. \& Hamed, G. (2010). Web-based writing instruction and enhancing EFL learners' writing quality. Turkish Online Journal of Distance Education-TOJDE, 12(3), $36-45$.

Kung, S. C. \& Chuo, T. W. (2002). Students' perceptions of English learning through ESL/EFL Websites. TESL-EJ, 6(1). Retrieved from http://tesl-ej.org/ej21/a2.html 
Lai, C. Y. (2008). A successful online English self-study program. Paper presented at the 25th Conference of English Teaching and Learning in the Republic of China, Chia-Yi County, Taiwan.

Lee, T. H., Shen, P. D., \& Tsai, C. W. (2008). Applying Web-Enabled Problem-Based Learning and Self-Regulated Learning to Add Value to Computing Education in Taiwan's Vocational Schools. Educational Technology \& Society, 11 (3), 13-25.

Lee, T. H., Shen, P. D., \& Tsai, C. W. (2010). Enhance low-achieving students' learning involvement in Taiwan's higher education: an approach via e-learning with problem-based learning and self-regulated learning. Teaching in Higher Education, 15(5), 553-565

Liao, Y. H. [廖熒虹] (2010). A preliminary study on technical college students' attitudes towards the English Benchmark Policy for Graduation [技專校院學生英語畢業門檻之態度 初探，國立虎尾科技大學學報], 29(3), 41-60.

Liao, Y. K. (2007). Effects of computer-assisted instruction on students' achievement in Taiwan: A meta-analysis. Computers \& Education, 48(2), 216-233.

Liaw, S. S. (2001). Designing the hypermedia-based learning environment. International Journal of Instructional Media, 28, 43-56.

Lin, C. T. (2007). The effectiveness of web-based lessons on English classes: A case study - the Multi-Language Learning Website by Tamkang University. Unpublished Master's thesis. Taipei: Tamkang University.

Liou, H. (1997). The impact of WWW texts on EFL learning. Computer Assisted Language Learning, 10(5), 455-478.

Liu, P. L., Chen, C. J., \& Chang, Y. J. (2010). Effects of a computer-assisted concept mapping learning strategy on EFL college students' English reading comprehension. Computers \& Education, 54(2), 436-445.

Liu, Y. (2007). A comparative study of learning styles between online and traditional students. Journal of Educational Computing Research, 37(1), 41-63.

Pan, C. \& Huang, P. (2009). The development and evaluation of a web-based college English outside reading system for EFL freshmen. JALT CALL, 5(3), 3-22.

Roberts, T. S. \& McInnerney, J. M. (2007). Seven problems of online group learning (and their solutions). Educational Technology \& Society, 10 (4), 257-268.

Shiu, J. D. (2002).The effects of Internet-assisted instruction and the cognitive styles of sixth graders on English achievement and motivation for learning English. Unpublished Master's thesis. Taiwan: National Ping-Tung Teachers College.

Sitzmann, T.M., Kraiger, K., Stewart, D. W., \& Wisher, R. A. (2006). The comparative effectiveness of web-based and classroom Instruction: A meta-analysis. Personnel Psychology, 59(3) 623-664. 
Son, J.-B. (2007). Learner experiences in web-based language learning. Computer Assisted Language Learning, 20(1), 21-36.

Son, J.-B. (2008). Using web-based language learning activities in the ESL classroom. International Journal of Pedagogies and Learning, 4(4), 34-43.

Su, S. W. [蘇紹雯] (2005). A study on the needs for the related regulations of Exit English Exam in Taiwan [英語畢業門檻相關規定之需求研究: 技職大學生的看法], Educational Review of the Kaohsiung Normal University in Taiwan, 24(6).

Sungur, S. \& Tekkaya, C. (2006). Effects of problem-based learning and traditional instruction on self-regulated learning. The Journal of Educational Research, 99, 307-317.

Tabassum, R. (2004). Effect of computer assisted instruction (CAI) on the secondary school students' achievement in science. Unpublished PhD thesis, University of Arid Agriculture, Rawalpindi.

Tanyeli, N. (2008). The efficiency of online English language instruction on students' reading skills. Paper presented at the International Technology, Education and Development Conference (INTED), Valencia, Spain.

The China Post Editorial (2007). TEFL scores in Taiwan: a humiliating failure. Retrieved from http://www.chinapost.com.tw/editorial/2007/08/24/119749/TEFL-scores.htm

The Liberty Times (2009). Only $0.74 \%$ of private university students passed the General English Proficiency Test (GEPT). [私大生 僅 $0.74 \%$ 通過英檢 ] Retrieved from http://www.libertytimes.com.tw/2009/new/sep/15/today-life10.htm

Tsao, C.H. \& Hsu, C. (2010). The English-learning needs of technical university students: A case study of Fooyin University. Journal of Lan Yang Institute of Technology, 9, 20-30.

Tsao, C. H. (2011). English for specific purposes in the EFL context: A Survey of student and faculty perceptions. Asian ESP Journal, 7(2), 125-149.

Warschauer, M. (2000). On-line learning in second language classrooms: An ethnographic study. In Network-based language teaching: Concepts and practice (pp. 41-58). New York: Cambridge University Press.

Wu, J. (2011). Validating GEPT scores against teacher and student assessments. Studies in English Language and Literature, 27, 141-152

$\mathrm{Wu}, \mathrm{W}$. S. (2004). Comparison of web-enhanced learning environments in an e-learning age. Paper presented at the 13th International Symposium on English Language Teaching, Taipei, Taiwan.

Yukselturk, E. \& Bulut, S. (2007). Predictors for student success in an online course. Educational Technology \& Society, 10(2), 71-83. 
Zhao, Y., Lei, J., Yan, B., Lai, C., \& Tan, S. (2005). What makes the difference? A practical analysis of research on the effectiveness of distance education. Teachers College Record, 107(8), 1836-1884.

\section{Appendix}

Appendix 1. Screen shots of online course website

\section{Web-Assisted Language Learning (WALL)}

\begin{tabular}{|l|l|l|l|l|}
\hline Listening & Reading & Vocabulary & Grammar & GEPT Practice \\
\hline
\end{tabular}

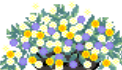

How Welcome to the WALL website created to help you learn English at the howbeginning to low-intermediate level. This site collects online learning resources that address listening, reading, vocabulary, grammar and test-taking skills accessible free of charge and prepares you to pass the elementary-level GEPT. You are required to complete the online assignments by following the study schedule and take class tests related to the assignments on the scheduled date.

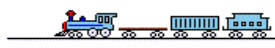

Course: Foreign Language Proficiency_Upper level

Instructor: Cindy Tsao

Email: cchtsao@yahoo.com.tw 


\section{Listening: Rendall's ESL Cyber Listening Lab}

(week 5 test \#1 6, week 11 test \#7 12)

Instructions First, click on the topic (start from number 1). Next, listen to the conversation by pressing the "Play Audio" button, and answer the multiple-choice questions. Then, press the "Final Score" button to check your quiz. If you are still unclear about the specifics of the conversation, go to Quiz Script. Finally, listen to the conversation again and take the Text Completion Quiz to train your dictation skills.

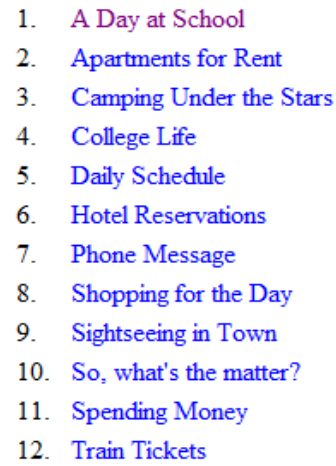

Below is a screen shot from the first listening topic.

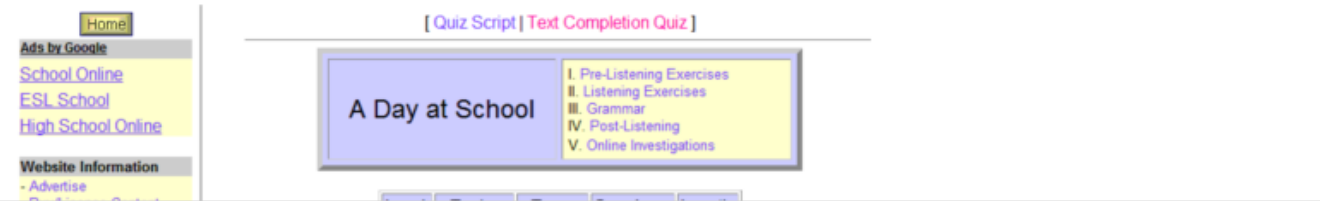

\section{Reading: Reading Station}

(week 7 test \#1 5, week 14 test \#6 10)

Instructions First, click on the topic (start from number 1). Next, read the article, and answer the multiple-choice questions at the same time. After you are done with all of the questions, you will see your score report pop up above. Finally, check your understanding of the article, and ask your teacher where you don't understand.

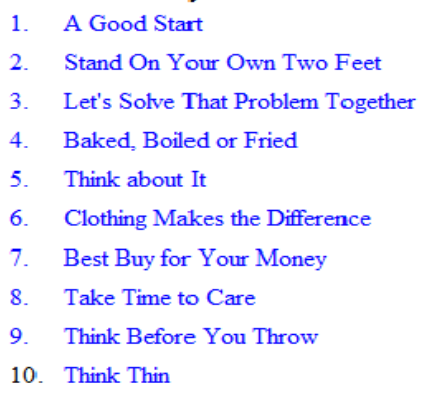

Below is a screen shot from the first reading topic.

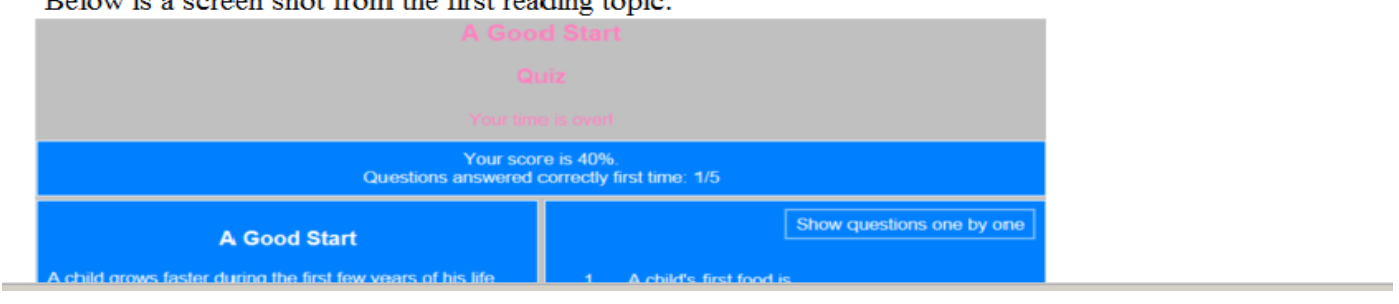




\section{Grammar: Basic English Grammar 븐}

Instructions There are 35 grammar diagnostic tests on the website. First, take one test each time. You may start with any test you like. Next, check your answers with the Answer Key. Then, read the explanation for the question you did wrong. Finally, take the upper-level test to see how much you have learned. Note: Try to work on two to three diagnostic tests each week so as to learn as many grammar rules as you can.

Below is a screen shot from the topic of Adjectives - Comparison and Superlative.

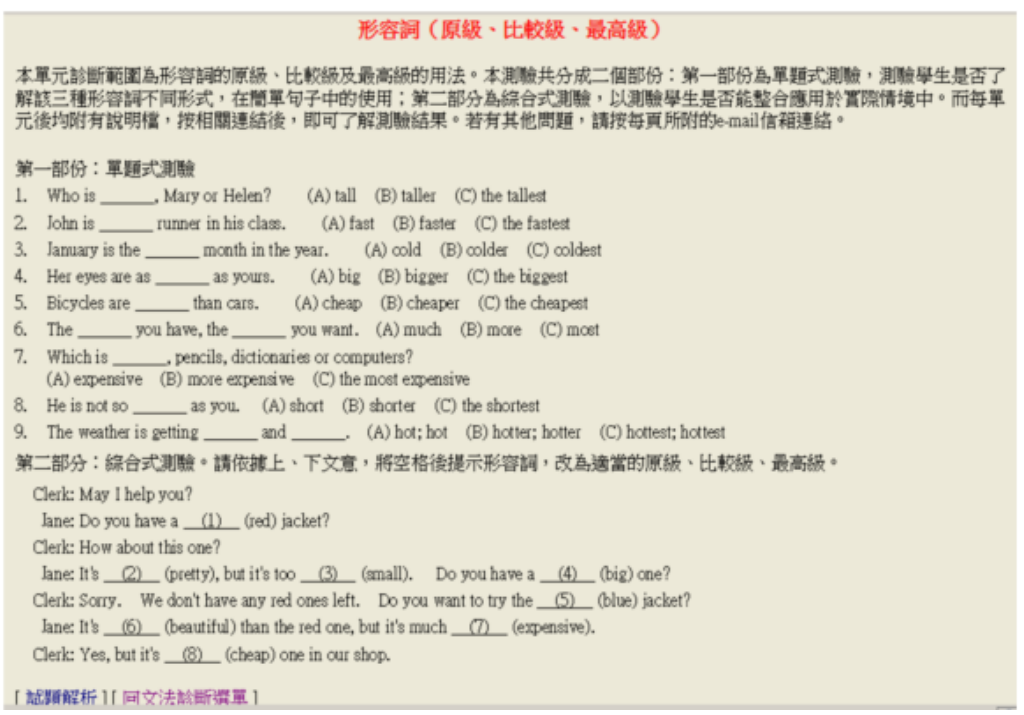

Appendix 2. Web-based Learning Interview Protocol

1. What do you think of the teacher-selected websites in terms of contents and difficulty levels?

2. How much time do you spend learning at these websites?

3. Does online learning help you learn English better? In what way is it most helpful?

4. Does online learning increase your interest in learning English? Why or why not?

5. Does online learning help you develop autonomous learning habit?? Why or why not?

6. What comments or suggestions would you like to make regarding the way how web-assisted instruction is implemented this semester?

Appendix 3. Sample of Students' study notes for one of the selected websites

\begin{tabular}{|l|c|c|c|c|c|}
\hline Name & \multicolumn{1}{l|}{ xxx } & \multicolumn{2}{l|}{ Student Number } & \\
\hline Name of Website & \multicolumn{4}{l|}{ Basic English Grammar } \\
\hline Dates of Learning & $12 / 1$ & $11 / 30$ & $11 / 10$ & $11 / 9$ & $11 / 8$ \\
\hline Accumulated hours & 3 & 1 & 2 & 1 & 2.5 \\
\hline
\end{tabular}




\begin{tabular}{|c|c|}
\hline Learning Content & 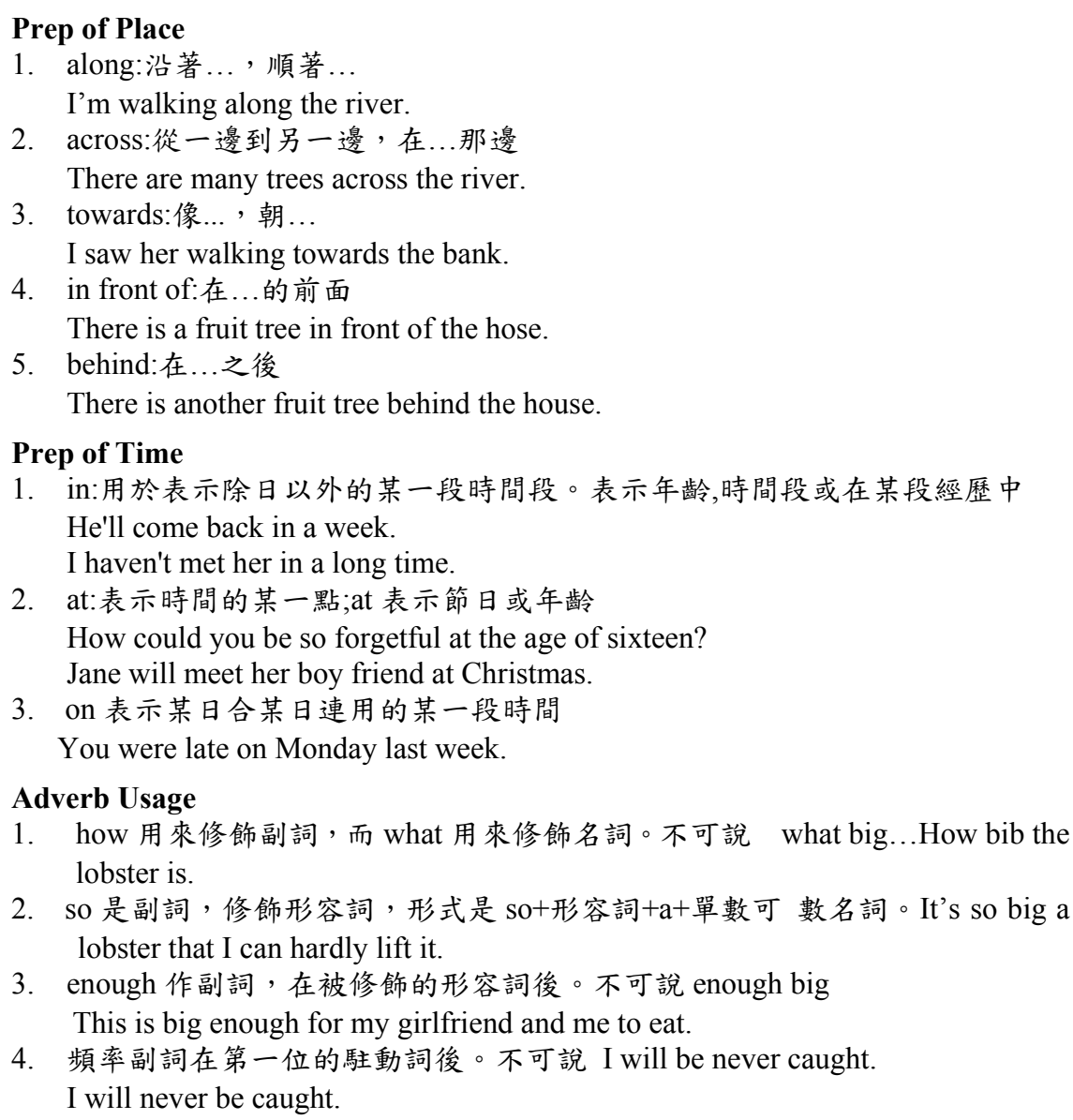 \\
\hline Reflections & $\begin{array}{l}\text { I have to say my grammar is really poor, I know how to write or say a complete } \\
\text { sentence, but I don't know how to put words together to make a correct English } \\
\text { sentence. If I don't use English for a long time, I will forget its word order. Although } \\
\text { I've always wanted to learn English grammar well since junior high school, I don't } \\
\text { know where to start. As a result, there are more and more rules I don't know and I } \\
\text { become very nervous. In junior high school I usually got high scores in English tests, } \\
\text { but I don't know what the scores meant because I couldn't speak or write in English. } \\
\text { After I entered junior college, my English became worse because the teacher here } \\
\text { didn't teach grammar in class. } \\
\text { I'm happy that in my second year of junior college, I had a different English teacher, } \\
\text { who forced us to learn English from the online websites. And I found this grammar } \\
\text { website is really useful. I gradually have some ideas of what grammar is. } \\
\text { Thank you, teacher, although my English grammar is still not good, I have made } \\
\text { some progress at least. (translated into English from the source language Chinese) }\end{array}$ \\
\hline
\end{tabular}

\section{Copyright Disclaimer}

Copyright for this article is retained by the author(s), with first publication rights granted to the journal.

This is an open-access article distributed under the terms and conditions of the Creative Commons Attribution license (http://creativecommons.org/licenses/by/3.0/). 